\title{
Sosialisasi Pengelolaan Keuangan Desa Kepada Aparatur Desa Untuk Pemberdayaan Masyarakat Di Desa Belangian Kecamatan Aranio Kabupaten Banjar
}

\author{
Gazali Rahman $1^{*}$, Achmad B̧ayu Chandrabuwono ${ }^{2}$, Difinka Nur Leviana ${ }^{3}$, Mawardah ${ }^{4}$, \\ Mega Mustika Tirtha Rahayu ${ }^{\text {, Muhammad Rifqi }}{ }^{6}$, Muhammad Ulul Amry ${ }^{7}$, Nor Nazhah ${ }^{8}$, \\ Sandri Alfandi ${ }^{9}$ \\ 1,2Fakultas Ilmu Sosial dan Ilmu Politik Universitas Lambung Mangkurat \\ Jl. H. Hassan Basry, Banjarmasin, Indonesia, \\ 3,4,5,6,7,8,9, Mahasiswa Program Studi Ilmu Pemerintahan ${ }^{3}$ Fakultas Ilmu Sosial dan Ilmu Politik \\ Universitas Lambung Mangkurat \\ J1. H. Hassan Basry, Banjarmasin, Indonesia, \\ *email korespondensi: gazalirahman.fisip@ulm.ac.id
}

Diajukan

29 Oktober 2021

Keywords:

Sosialisasi

Manajemen Keuangan Desa

Desa Belangian

Pengabdian Masyarakat

\section{Informasi Artikel}

Diterima

20 November 2021
Diterbitkan

30 November 2021

\begin{abstract}
The purpose of this community service is to carry out programs and activities funded by the village income and expenditure budget, administering village financial transactions using the village accounting model, so as to be able to make transparent and accountable village financial reports. With the enactment of Law Number 6 of 2014 concerning Villages, the village government will obtain large enough funds and must be managed properly and can be accounted for. The method of implementing this activity uses data collection methods to collect data by analyzing the realization of the Village Revenue and Expenditure Budget (APBDes) documents, and conducting interviews with village government officials with the Village Consultative Body (BPD). The data analysis method used is a village accounting model to discuss problems, using an analysis of the village accounting model and existing regulations in the village. Socialization activities using data collection methods are very precise, this is really needed according to the needs of village officials, the impact of this socialization is to increase the knowledge of village officials in managing village finances as well as possible.
\end{abstract}

\begin{abstract}
ABSTRAK
Tujuan pengabdian ini untuk melaksanakan program dan kegiatan yang didanai oleh anggaran pendapatan dan belanja desa, penatausahaan transaksi keuangan desa dengan menggunakan model akuntansi desa, sehingga mampu membuat laporan keuangan desa yang transparan dan akuntabel. Dengan berlakunya Undang-undang Nomor 6 Tahun 2014 tentang Desa, akan membuat pemerintah desa akan memperoleh dana yang cukup besar dan harus dapat dikelola dengan baik dan dapat dipertanggungjawabkan. Metode pelaksanaan kegiatan ini menggunakan metode pengumpulan data untuk mengumpulkan data di lakukan dengan cara menganalisis dokumen relalisasi Anggaran Pendapatan dan Belanja Desa (APBDes), dan mengadakan wawancara dengan aparatur pemerintahan desa dengan Badan Permusyawaratan Desa (BPD). Metode analisis data yang digunakan adalah model akutansi desa untuk membahas permasalahan, menggunakan analisis model akuntansi desa dan regulasi yang ada di desa. Kegiatan sosialisasi menggunakan metode pengumpulan data sangat tepat, hal ini sangat diperlukan sesuai dengan kebutuhan oleh para aparatur desa, dampak sosialisasi ini untuk meningkatkan pengetahuan para aparatur desa dalam mengelola keuangan desa dengan sebaik-baiknya.
\end{abstract}

\section{Copyright and License:}

Authors retain copyright and grant the journal right of first publication with the work simultaneously licensed under a Creative Commons Attribution 4.0 International License that allows others to share the work with an acknowledgment of the work's authorship and initial publication in this journal.

Journal homepage: https://ojs.wiindonesia.com/index.php/jecsr 


\section{PENDAHULUAN}

Desa adalah desa dan desa adat atau yang disebut dengan nama lain, selanjutnya disebut Desa, adalah kesatuan masyarakat hukum yang memiliki batas wilayah yang berwenang untuk mengatur dan mengurus urusan pemerintahan, kepentingan masyarakat setempat berdasarkan prakarsa masyarakat, hak asal usul, dan/atau hak tradisional yang diakui dan dihormati dalam sistem pemerintahan Negara Kesatuan Republik Indonesia. Keuangan Desa adalah semua hak dan kewajiban Desa yang dapat dinilai dengan uang serta segala sesuatu berupa uang dan barang yang berhubungan dengan pelaksanaan hak dan kewajiban Desa. Pengelolaan Keuangan Desa adalah keseluruhan kegiatan yang meliputi perencanaan, pelaksanaan, penatausahaan, pelaporan, dan pertanggungjawaban keuangan desa. Rencana Kerja Pemerintah Desa (RKPDesa) merupakan penjabaran dari Rencana Pembangunan Jangka Menengah Desa untuk jangka waktu 1 (satu) tahun. keuagan desa adalah semua hak dan kewajiban desa yang dapat dinilai dengan uang serta segala sesuatu berupa uang dan barang yang berhubungan dengan pelaksanaan hak dan kewajiban desa. pengelolaan keuangan desa adalah keseluruhan kegiatan yang meliputi perencanaan,pelaksanaan, penatausahaan, pelaporan, dan pertanggungjawaban keuangan desa. rencana kerja pemerintah desa (RKPDesa) merupakan penjabaran dari rencanapembangunan jangka menengah desa untuk jangka waktu 1 (satu) tahun. anggaran pendapatan dan belanja desa (APBDesa) merupakan rencana keuangan tahunan pemerintahan desa. diperlukan peraturan Bupati/walikota untuk mengatur mengenai pengelolaan keuangan desa.

Peraturan Menteri Dalam Negeri No.20 Tahun 2018 menyebut bahwa pengelolaan keuangan desa meliputi keseluruhan kegiatan yang meliputi perencanaan, pelaksanaan, penatausahaan, dan pertanggungjawaban keuangan desa. Pengelolaan keuangan desa merupakan rangkaian siklus yang terpadu dan berintegrasi antara satu tahapan dengan tahapan yang lainnya. Keuangan desa dikelola berdasarkan asas-asas transparan, akuntabel, partisipatif, serta dilakukan dengan tertib dan disiplin anggaran. Rangkaian dan asas pengelolaan keuangan desa harus dilaksanakan dan dipenuhi oleh setiap desa agar penyelenggaraan pemerintahan, pelaksanaan pembangunan desa, pembinaan masyarakat desa, dan pemberdayaan masyarakat desa dapat berjalan sesuai dengan rencana sehingga visi desa dan masyarakat yang sejahtera dapat diwujudkan. Dengan berlakunya Undang-undang Nomor 6 Tahun 2014 tentang Desa, akan membuat pemerintah desa akan memperoleh dana yang cukup besar dan harus dapat dikelola dengan baik dan dapat dipertanggungjawabkan.

Pengelolaan keuangan desa tidak hanya menyangkut perlunya peraturan pendukungnya dan sarana-prasarana, namun yang paling penting adalah sumber daya manusia yang memiliki kompetensi dan komitmen yang dapat diandalkan. Kita sadari bahwa kepala desa dan aparatur desa yang ada saat ini sebagian besar memiliki tingkat pendidikan SMTA, pengetahuan tentang akuntansi dan penatausahaan dalam pengelolaan keuangan desa relatif rendah, sehingga mengalami kesulitan dalam melakukan pencatatan transaksi keuangan desa, dan hal ini tidak bisa dianggap remeh karena bila terjadi kesalahan maka akan menyebabkan semuanya menjadi salah. Kondisi seperti ini tentu akan menyulitkan dalam penatausahaan dan mempertanggungjawab-kan keuangan desa.

Untuk itu pengelolaan keuangan desa terutama pada tahap penatausahaan keuangan desa, menjadi hal yang penting dalam menjamin kualitas laporan keuangan desa yaitu melakukan pencatatan penerimaan dan pengeluaran keuangan desa serta melakukan tutup buku setiap akhir bulannya sampai menyusun laporan keuangan desa. Maka diperlukan pemahaman tentang akuntansi dan penatausahaan keuangan dalam pengelolaan keuangan desa kepada sebagian besar kepala desa dan aparatur desa sehingga mereka mampu mempertanggungjawabkannya. Oleh karena itu kehadiran model akuntansi sangatlah tepat dan sangat dibutuhkan untuk mengatasi masalah tersebut sebagai solusinya. Perlu dirancang sebuah model akuntansi desa yang mudah, sederhana dan jelas serta disertai contoh aplikasi pembahasannya sehingga dengan mudah dapat dipahami dan dilaksanakan oleh kepada desa dan aparatur desa dalam melakukan penatausahaan keuangan desa yang dimulai dari pencatatan transaksi keuangan desa, jurnal, posting ke rekening besar, neraca saldo, ayat jurnal penyesuaian, dan penyusunan laporan keuangan desa yang transparan dan akuntabel.

\section{METODE}

Pengelolaan keuangan desa adalah seluruh kegiatan yang meliputi kegiatan perencanaan, pelaksanaan, penatausahaan, pelaporan, dan pertanggungjawaban keuangan desa. Adapun metode yang dilakukan dalam kegiatan Kuliah Kerja Nyata FISIP Universitas Lambung Mangkurat tahun 2021 oleh 
kelompok 9 di desa Belangian ini adalah sosialisasi tentang pengelolaan keuangan desa yang berjudul "Sosialisasi Pengelolaan Keuangan Desa Kepada Aparatur Desa Untuk Pemberdayaan Masyarakat di Desa Belangian Kecamatan Aranio Kabupaten Banjar" dengan dua sesi yaitu sesi penyampaian materi dan sesi diskusi tanya jawab. Menurut KBBI sosialisasi sendiri merupakan upaya memasyarakatkan sesuatu sehingga menjadi dikenal, dipahami, dihayati oleh masyarakat. Proses sosialisasi merupakan pendidikan sepanjang hayat melalui pemahaman dan penerimaan individu atas peranannya di dalam suatu kelompok. Tujuan dari adanya sosialisasi adalah mengajarkan sesuatu atau kebudayaan yang berlaku dalam suatu kelompok kepada individu dari segi peran dan status sosial. Dalam arti sempit, sosialisasi merupakan proses memperkenalkan sebuah sistem pada seseorang dan bagaimana orang tersebut menentukan tanggapan serta reaksinya.

\section{HASIL DAN PEMBAHASAN}

Kuliah Kerja Nyata FISIP Universitas Lambung Mangkurat tahun 2021 oleh kelompok 9 yang dilakukan di desa Belangian memiliki beberapa program kerja, salah satunya adalah "Sosialisasi Pengelolaan Keuangan Desa Kepada Aparatur Desa Untuk Pemberdayaan Masyarakat di Desa Belangian Kecamatan Aranio Kabupaten Banjar". Sosialisasi ini dilakukan oleh Mahasiswa Program Studi Ilmu Pemerintahan FISIP Universitas Lambung Mangkurat kepada Aparatur Desa Belangian. Adapun tahapan yang dilakukan pada kegiatan Kuliah Kerja Nyata FISIP Universitas Lambung Mangkurat tahun 2021 dengan metode sosialisasi tersebut adalah sebagai berikut :

\section{Tahap Persiapan}

Tahap awal yang dilakukan pada kegiatan Kuliah Kerja Nyata FISIP Universitas Lambung Mangkurat tahun 2021 oleh kelompok 9 yang berupa sosialisasi ini adalah dengan melakukan beberapa persiapan yaitu :

1. Melakukan survei langsung ke lokasi tempat sosialisasi akan berlangsung.

2. Menentukan tema dan topik dari kegiatan sosialisasi.

3. Menentukan tempat dan waktu berlangsungnya kegiatan sosialisasi.

4. Mempersiapkan materi yang akan disampaikan serta mempersiapkan peralatan yang dibutuhkan pada kegiatan sosialisasi.

5. Mengundang Aparatur Desa Belangian untuk dapat berhadir dalam kegiatan sosialisasi.
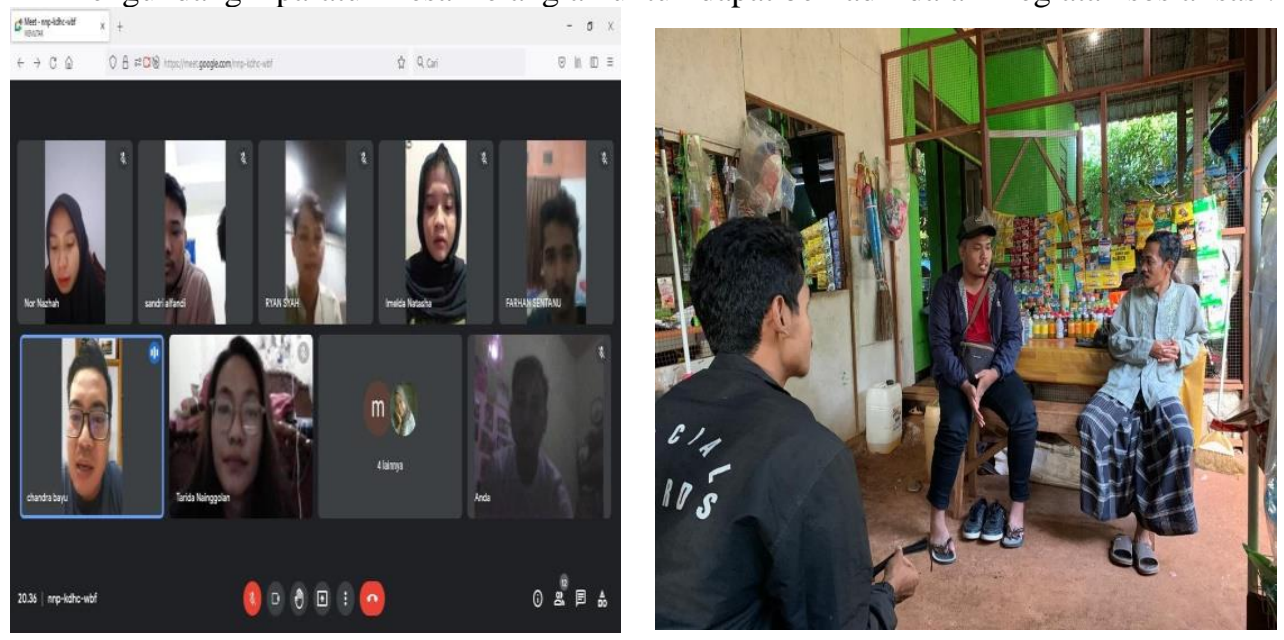

Gambar 1 Tahapan Persiapan Sosialisasi dan Survei Lapangan

\section{Tahapan Pelaksanaan}

Tahap selanjutnya pada kegiatan ini adalah tahapan pelaksanaan sosialisasi. Sosialisasi pengelolaan keuangan desa kepada Aparatur Desa untuk pemberdayaan masyarakat di desa Belangian kecamatan Aranio kabupaten Banjar dilaksanakan pada hari Sabtu, 04 September 2021 di sekre Karang Taruna desa Belangian. 

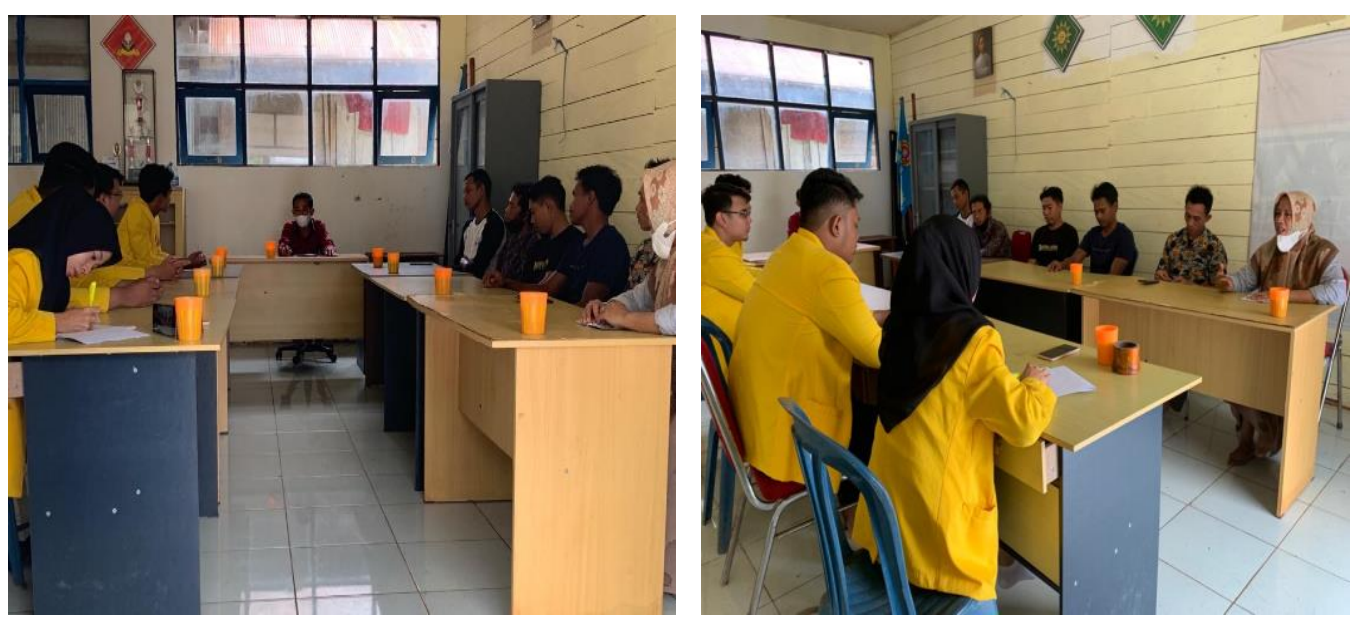

Gambar 2 Kegiatan Pelaksanaan Sosialisasi

\section{Hasil Kegiatan}

Capaian atau hasil dari diadakannya kegiatan sosialisasi pengelolaan keuangan desa kepada Aparatur Desa untuk pemberdayaan masyarakat di desa Belangian kecamatan Aranio kabupaten Banjar ini seacara umumnya adalah diharapkan Aparatur Desa dapat melakukan pengelolaan keuangan desa dengan efektif dan efesien terhadap pemberdayaan masyarakat yang ada di desa Belangian tersebut. Adapun secara khusus capaian yang didapatkan adalah informasi mengenai pengelolaan keuangan desa Belangian tersebut yang didapatkan dalam sesi diskusi tanya jawab pada kegiatan sosialisasi tersebut yaitu rincian dana desa Belangian dikelola melalui beberapa tahapan yang dimulai dengan penyusunan Rencana Pembangunan Jangka Menengah Desa atau yang sering disebut RPJMDes, kemudian disusul dengan menyusun Rencana Kerja Pemerintah Desa yang disingkat RKPDes. Usai melaksanakan penyusunan RKPDes, dilanjutkan dengan menyusun Anggaran Pendapatan dan Belanja Desa atau APBDes sehingga terlaksana pembangunan desa lewat Dana Desa tersebut.

Pada tahun 2021, Pemerintah Desa Belangian Kecamatan Aranio memiliki APBDes sebanyak Rp 1,1 Miliar yang diperoleh dari APBN senilai Rp 680 Juta dan bersumber dari Desa sebesar Rp 140 Juta, dari beragam kegiatan atau event yang berhubungan dengan APBDes, Desa Belangian selalu dilakukan pembinaan oleh Badan Pengawas Keuangan dan Pembangunan (BPKP) serta Inspektorat terkait penggunaan Dana Desa.

Adapun pendapatan pada Desa Belangian diperoleh dari sejumlah Badan Usaha Milik Desa (BUMDes) diantaranya Perkebunan Karet, Kacang Tanah, Cabai, Pisang dan Padi Gunung, selain itu ada juga Perikanan dan Pertanian. Selain itu terdapat pula Badan Permusyawaratan Desa (BPD) yang saat ini sudah berusia kurang lebih 2 tahun sejak didirikan pada bulan Februari tahun 2020, sedikitnya melalui BPD tersebut dibentuk beberapa Peraturan Desa (Perdes) yang diantaranya Perdes Kesehatan, Keamanan, APBDes, Kewenangan, Kebersihan dan Realisasi.

Selanjutnya Perdes yang rencananya akan dibentuk adalah Administrasi Pemerintahan serta penerbitan Rencana Anggaran Biaya Sementara (RABS) melalui Website Pemerintah Desa. Pemerintah Desa Belangian bersama Aparatur dan BPD terus berupaya memberdayakan masyarakat melalui kegiatan organisasi desa yang bertujuan menunjang minimnya fasilitas pendidikan dengan semangat kebersamaan dan pemerintahan yang fleksibel didukung dengan informasi tepat sasaran. Mereka pun juga bergotong royong bahu membahu membuat wadah pembinaan bagi generasi muda dengan dihadirkannya tenaga ahli untuk menunjang kemajuan desa seperti tenaga ahli di bidang peternakan yang sudah berjalan beberapa waktu.

Adapun rincian kekurangan pada Desa Belangian yaitu, tidak adanya akses internet, jalan atau transportasi serta jarak yang jauh dengan kota membuat kurangnya lapangan pekerjaan, kurangnya akses pemasaran, kurangnya pembangkit listrik dan minimnya partisipasi pemuda. 

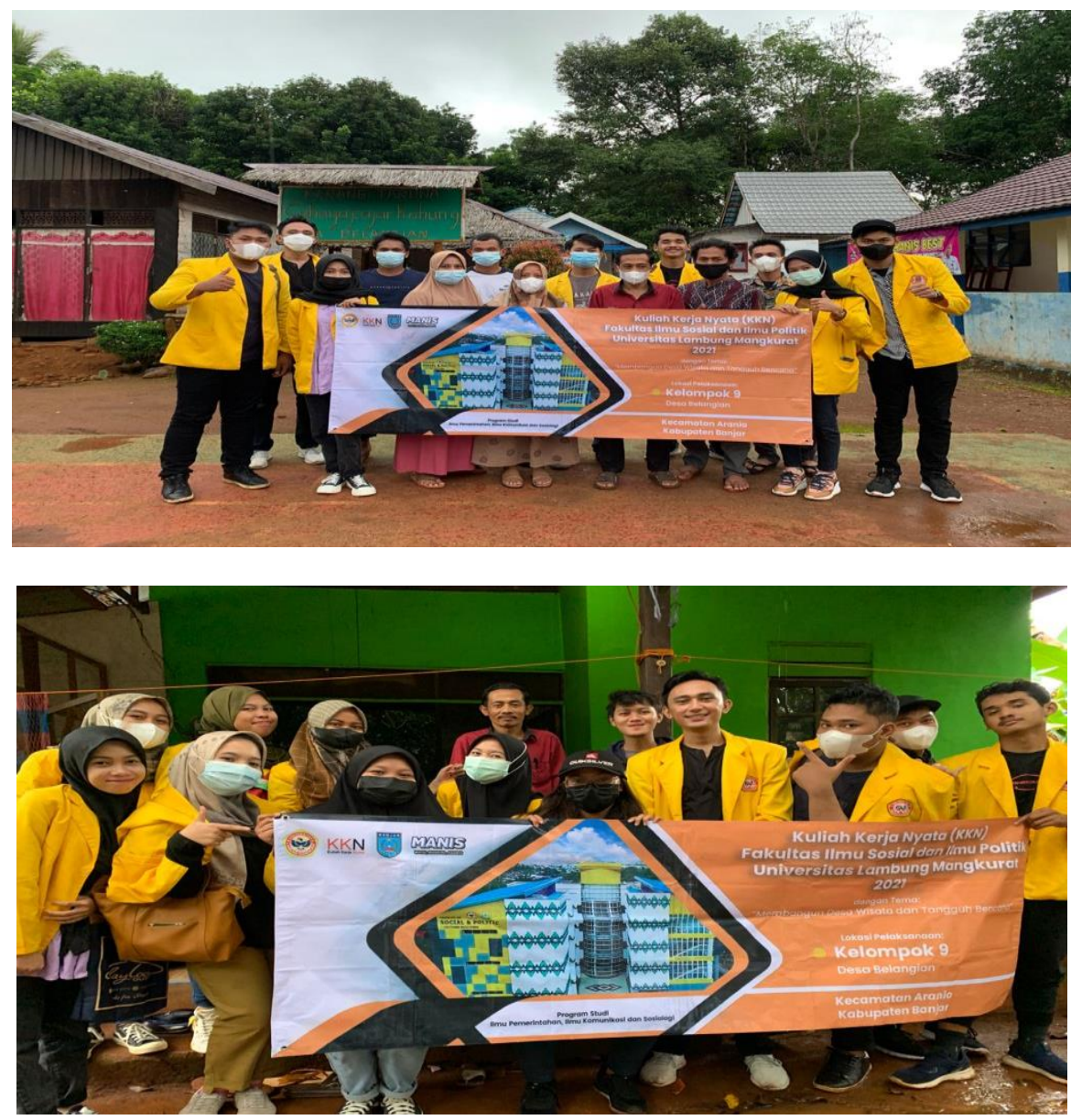

Gambar 3 Dokumentasi bersama Aparatur Desa Belangian

\section{KESIMPULAN}

Peraturan Menteri Dalam Negeri No. 20 Tahun 2018 Menyebut bahwa Pengelolaan Keuangan desa meliputi keseluruhan kegiatan yang meliputi perencanaan, pelaksanaan, penatausahaan, dan pertanggung jawaban keuangan desa. Pengelolaan keuangan desa tidak hanya menyangkut perlunya peraturan pendukungnya dan sarana-prasarana, namun yang paling penting adalah sumber daya manusia yang memiliki kompetensi dan komitmen yang dapat diandalkan. Untuk itu pengelolaan keuangan desa terutama pada tahap penatausahaan keuangan desa, menjadi hal penting dalam menjamin kualitas laporan keuangan desa yaitu pencatatan penerimaan dan pengeluaran keuangan desa (laporan keuangan).

Maka dari itu adapun yang dilakukan dalam kegiatan Kuliah Kerja Nyata FISIP Universitas Lambung Mangkurat tahun 2021 oleh kelompok 9 di Desa Belangian ini yaitu sosialisasi perihal Pengelolaan Keuangan Desa Kepada Aparatur Desa Untuk Pemberdayaan Masyarakat di Desa Belangian Kecamatan Aranio Kabupaten Banjar. Sosialisasi ini dilakukan oleh Mahasiswa Program Studi Ilmu Pemerintahan FISIP Universitas Lambung Mangkurat Tahun 2021.

Dengan menggunakan metode sosialisasi yang melingkup beberapa tahapan yaitu tahap persiapan dan tahap pelaksanaan, diperolehlah hasil kegiatan berupa beberapa informasi diantaranya Pada tahun 2021 pemerintah Desa Belangian Kecamatan Aranio memiliki APBDes sebanyak 1,1 M yang diperoleh dari APBN senilai Rp, 680 juta dan bersumber dari desa sebesar Rp 140 juta. Adapun pendapatan pada desa belangian ini diperoleh dari Badan Usaha Milik Desa (Bumdes) diantaranya sektor perkebunan, perikanan, dan pertanian. Dalam perihal pengelolaan dana desa di desa belangian di bawah naungan BPKP dan inspektorat, mengingat di desa masih kurangnya akses internet, kelistrikan, jalan dan transportasi, maka pemerintah desa bersama aparatur dan BPD berusaha memberdayakan masyarakat melalui sosisalisasi dan membentuk organisasi guna membangun desa, setidaknya hal tersebut terlihat 
melalui BPD tersebut dibentuk beberapa peraturan desa, (Perdes) yang diantaranya Perdes kesehatan, keamanan, APBDes, kewenangan, kebersihan, dan realisasi.

\section{UCAPAN TERIMA KASIH}

Ucapan terima kasih disampaiakn kepada FISIP Universitas Lambung Mangkurat yang telah mendukung terlaksananya kegiatan ini.

\section{REFERENSI}

Tujuan Sosialisasi dalam Masyarakat, Pengertian, Tahapan, dan Jenis. Tersedia pada https://id.berita.yahoo.com . Diakses pada 25 September 2021.

Mardatila, Ani. 2020. "Mengenal Tujuan Sosialisasi, Jenis dan Penjelasannya Menurut Para Ahli". Tersedia pada https://www.merdeka.com/sumut/tujuan-sosialisasi-jenis-pengertian-menurut-para-ahlidan-medianya-kln.html . Diakses pada 27 September 2021.

Zigoes. 2020. "Pengelolaan Keuangan Desa : Perencanaan". Tersedia pada http://wikeuangan.com/pengelolaan-keuangan-desa-perencanaan-detail-404704.html . Diakses pada tanggal 27 september 2021.

Agus, Puji. 2015. "Pengelolaan Keuangan Desa: Sistem dan Prosedur Pertanggungjawaban Keuangan Desa". Tersedia pada https://bppk.kemenkeu.go.id/content/berita/balai-diklat-keuangan-cimahipengelolaan-keuangan-desa-sistem-dan-prosedur-pertanggungjawaban-keuangan-desa-2019-11-05-

6e15d0e3/. Diakses pada 27 september 2021. 